\title{
電気生理学から見えてくる微生物型ロドプシンの イオン輸送メカニズム
}

\author{
角田 聡 JSTさきがけ/名古屋工業大学客員准教授
}

\begin{abstract}
The microbial rhodopsins are a class of membrane proteins with seven transmembrane helices harboring an all-trans retinal retinal chromophore. The functions of microbial rhodopsins are diverse, including light-driven cation and anion pumps, light-gated cation and anion channels, positive and negative phototaxis sensors, photochromic sensors, and light-activated enzymes. Here I focus on the ion-transporting rhodopsins and explain the mechanism of the pumps and the channels revealed by the electrophysiological studies. Characteristics of light-gated cation channel (channelrhodopsins) and proton-pumping rhodopsins are discussed.
\end{abstract}

membrane protein / microbial rhodopsin / channelrhodopsin / ion-pumping rhodopsin / electrophysiology

1.

\section{は己゙めに一広がるイオン輸送型ロドプシンの仲間}

生体膜は細胞や細胞小器官（オルガネラ）を囲む 膜構造であるが，単に外と内を隔てる静的な構造体 ではなく，イオンなどの低分子の出入りは常に制御 されている. その出入りを担らのが生体膜に存在す る様々な輸送体タンパク質であり，受容体による細 胞外シグナルの感受，ATP 合成酵素等よる生体エネ ルギー変換など細胞にとって重要な機能を担ってい る。また神経細胞に拈いては，その膜電位差の変化 によって発生する活動電位が脳細胞の情報として神 経回路を伝播する.

数ある輸送体膜タンパク質の中でも膜内外のイオン 輸送を担らのがイオンポンプ，イオンチャネルと呼ば れる分子である。 イオンポンプは化学エネルギー等を 消費して膜内外のイオン濃度勾配に逆らって一方向に イオンを能動輸送することで電気化学ポテンシャル差 を作り出す。一方イオンチャネルは膜間の電気化学ポ テンシャルに沿ってイオンを受動輸送する。つまりイ オン濃度の高いほうから低い浪らへ，膜電位の高いほ らから低い注らへイオンを通す。光受容体である微生 物型ロドプシンは, 7 回膜貫通型の膜タンパク分子で 発色団として all-trans 型のレチナールを分子内に結合 している。この仲間には光エネルギーでイオンを輸送 するポンプ型分子や，光で開閉するイオンチャネル型 分子が存在する（図 1 $)^{1)}$ 。前者は古細菌 Halobacterium salinarium 由来のプロトンポンプであるバクテリオロド プシン (bacteriorhodopsin, BR） やクロライドイオンポ ンプであるハロロドプシン (halorhodopsin, HR) 等が よく知られており，1970年代から特に分光学や構造学 を中心に詳細な研究が行われてきた。 さらに2000年 以降になると環境中の様々な微生物の網羅的な遺伝子 解析（メタゲノム解析）が活発になり，古細菌以外に も様々な生物が微生物型ロドプシン遺伝子を持つこと がわかってきた，その中でも特に海洋に生息する真正 細菌から，BRやHR と同様にプロトンポンプやクロ ライドポンプ機能を示す分子が多数見つかっている. さらに 2013 年には井上らによってナトリウムイオン とプロトンの両方をポンプする分子である NaRが発 見された ${ }^{2)}$. 続いて 2016 年, Parvularcula oceani という 海洋性細菌からプロトンを BR とは逆の細胞内へ向け て能動輸送するポンプが発見され PoXeR と名付けら れた ${ }^{3)}$.

一方イオンチャネル型ロドプシンは, 2002 年と 2003 年にChlamydomonas reinhardtii 由来の光開閉型カ チオンチャネルであるチャネルロドプシン $1(\mathrm{ChR} 1)^{4)}$ とチャネルロドプシン $2(\mathrm{ChR} 2)^{5)}$ が発見されたのを 皮切りに，近縁の生物から相同性の高い分子が次々に 見つかってきている ${ }^{6)}$. これらの光開閉型カチオン チャネルの神経細胞の光操作ッールとしての応用は, 光遺伝学といら新たな分野を切り開いた ${ }^{7), 8)}$.ささら 2015 年にはカチオンではなくアニオンチャネルであ

Ion Transport Mechanism of the Microbial Rhodopsins Revealed by Electrophysiological Studies

Satoshi TSUNODA ${ }^{1,2}$

${ }^{1}$ PREST, Japan Science and Technology Agency (JST)

${ }^{2}$ Department of Life Science and Applied Chemistry, Nagoya Institute of Technology 


\section{チャネル}

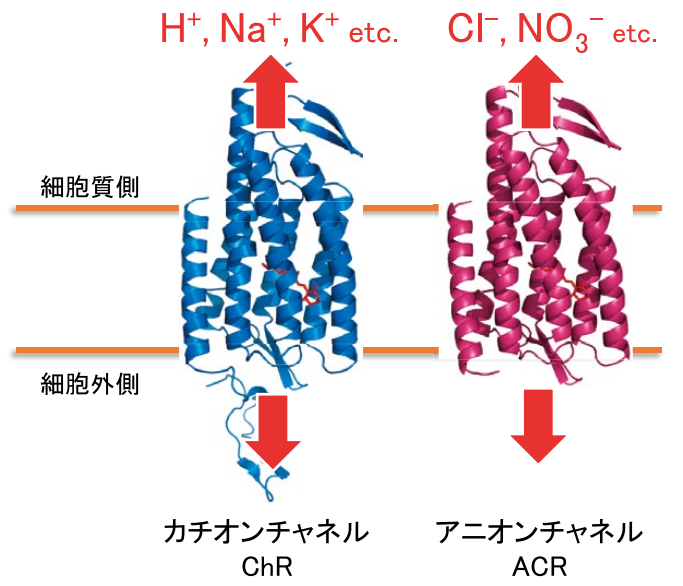

\section{ポンプ}

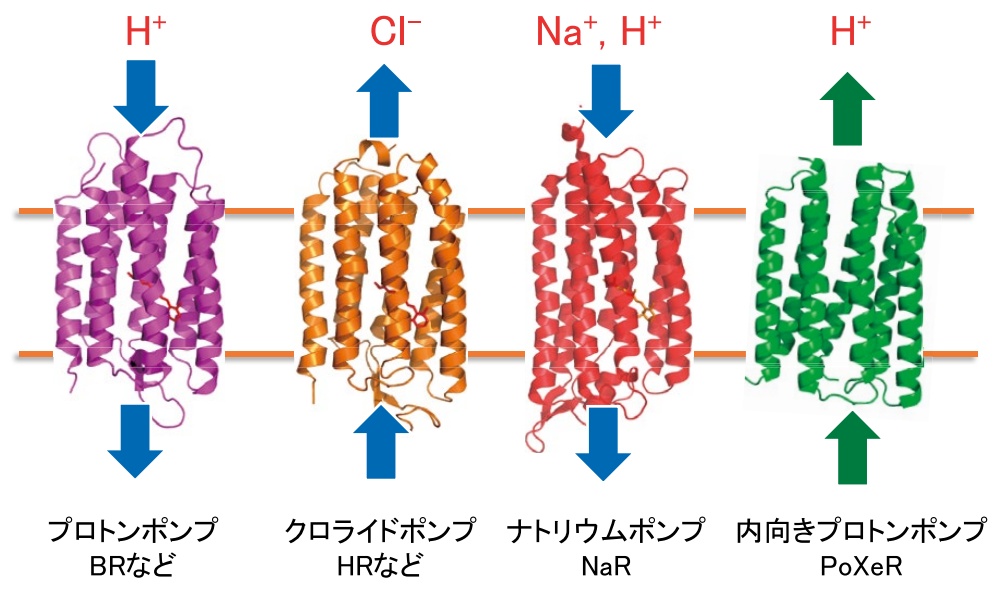

図 1

様々なイオン輸送性を示す微生物型ロドプシンの仲間. 光開閉型イオンチャネル（ChR，ACR）と光駆動型イオンポンプ（BR，HR，NaR， PoXeR). それぞれの分子の機能と輸送するイオン種を示す. ChR, BR, HR, NaR は各分子の結晶構造を示す. ACR と PoXeR はモデル構造. PDB accession numbers; 3UG9, 2AT9, 1E12, 3X3B.

る ACR1 やACR2 がクリプト藻の一種である Guillardia theta から発見されている ${ }^{9)}$.

このようにイオン輸送性のロドプシンは多様な機能 を持つことが明らかになりつつある，本稿では，特に プロトンポンプ型ロドプシンとチャネルロドプシンを 中心に，イオン輸送を直接測る電気生理学研究から見 えてきたイオン輸送機構について紹介したい.

\section{2.}

イオン輸送型ロドプシンの電気生理学渭定のねらい

イオン輸送型ロドプシンは不思議な分子である．同 じ 7 回膜貫通タンパク質，かつアミノ酸配列もよく似 ているのにもかかわらず一方はポンプ，もら一方は チャネルとして機能する（図 1,2）。ロドプシン一分 子の内部をイオンが通るという点でも同じであり， KcsA カリウムチャネルのように4 量体を形成してそ の中心にイオンの通り道を作るわけではない。一体ど こから機能の差が生じるのか?

また，ポンプ型ロドプシンがイオンを能動輸送する 時，乗り越えられるエネルギー障壁（電気化学ポテン シャル差）の大きさはどれくらいか? 細胞膜電位や輸 送されるイオンの濃度勾配がイオン輸送機能にどのよ らな影響を及ぼすのか? チャネル型ロドプシンのイオ ン選択性は?チャネルゲートの開閉の速度は?このよ らな疑問に答えるためにパッチクランプ法などの電気 生理学測定は威力を発揮する。 パッチクランプ法にお いては対象となるイオン輸送体を細胞膜に発現させ， イオン輸送を電流値として直接測定する ${ }^{10)}$. 大きな利

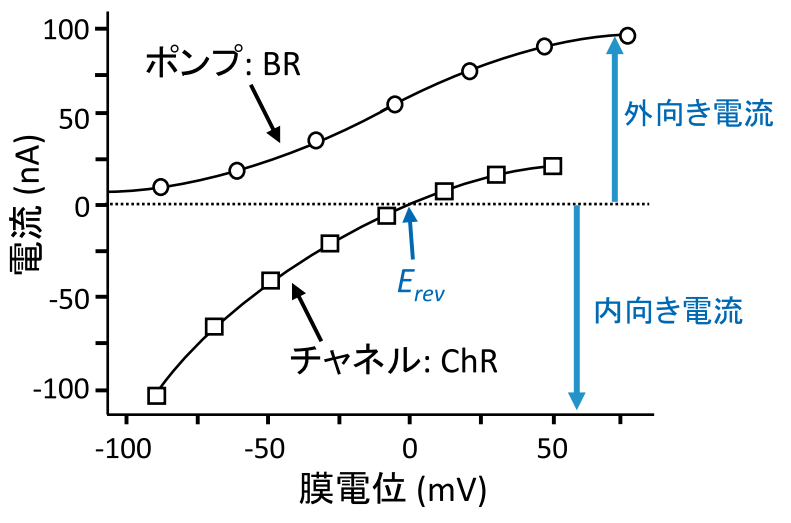

図 2

イオンチャネルとイオンポンプ. 膜電位とイオン輸送方向（イオ ン電流）の関係. BRのようなイオンポンプでは（太線），膜電位 にかかわらず常に細胞の内側から外側に向かってプロトンの移動 （外向き電流）が観察される. 一方 ChR などのイオンチャネルで は膜電位によって電流の向きが変わる (細線). 正の膜電位 (細胞 内が細胞外より電位が高い）時, 外向きにカチオンが流れ電流值 が正となり，負の膜電位（細胞内が細胞外より電位が低い）時, 内向きにカチオンが輸送され負の電流值となる. イオンチャネル において電流值がゼロになる膜電位を反転電位 (reversal potential: $\left.E_{r e v}\right)$ と呼ぶ（青の矢印）

点は膜内外イオン環境を独立に操作可能ならえ，電位 固定法を用いれば膜電位も厳密に設定可能である。ま た 10 マイクロ秒程度までの時間分解能を持ち，チャ ネル分子の開閉イベント等の分子機能を観察すること ができる。このよらな利点を生かして上記の謎に迫る のがねらいである。 
3.

\section{イオンチャネル型ロドブシン}

\section{1 チャネルロドプシン（ChR）}

2002 年の ChR1 の発見以来, ChRのイオンチャネル 活性はパッチクランプ法等の電気生理学的手法を用い て調べられてきた ${ }^{4), 5)}$. HEK293 培養細胞やアフリカ ツメガエル卵母細胞等にChR遺伝子を発現させ, 電位 固定法によりチャネル活性の電位依存性，イオン選択 性，チャネル活性化，不活性化の速度，照射光波長依 存性等様々な解析が行われている. 図 $3 A$ に各膜電位 に固定した際に得られたチャネル電流卜レースを重ね 合わせた戝を示す。ChR2を発現した細胞に青色光を 照射するとプロトンとカチオンの透過によるチャネル 電流が発生する. 電流の向きは膜電位や溶液中のイオ ン組成によって決まる電気化学ポテンシャルに沿った 向きに流れる。つまり，細胞膜の内と外で，プロトン やカチオン濃度の高い浪らから低い注らへ, 膜電位の 高い汪らから低い注らへイオンが輸送される（図 2, 3B). 図3Aの各トレースを見ると，光照射直後に大 きな一過性のピーク電流が現れる (transient peak)。そ れが数百ミリ秒後には減衰し定常電流となる（steady state)。これはChRの脱感作と呼ばれ，チャネル開状 態から遷移した閉状態の中間体の蓄積により見かけ上 の活性が下がることに起因する。光照射を止めると

A
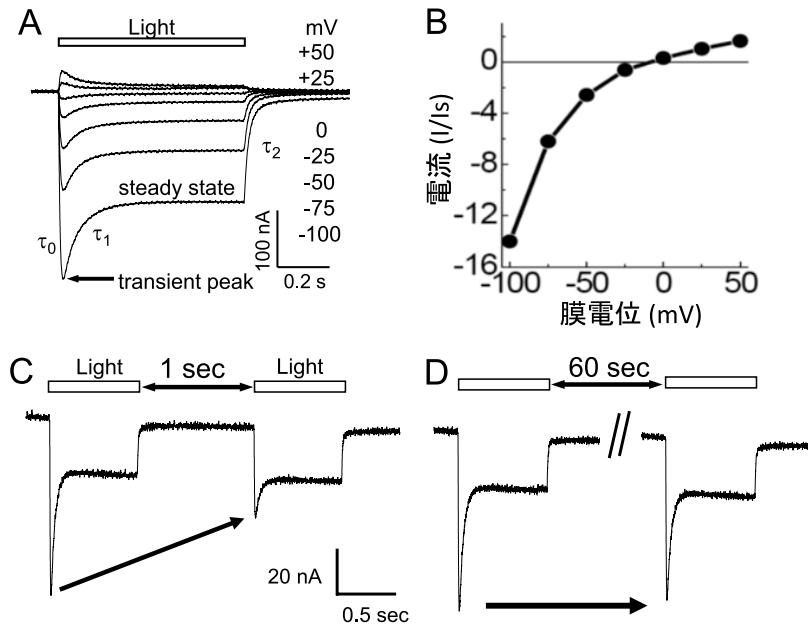

図 3

チャネルロドプシン 2 (ChR2) の電位固定法によるチャネル電流 測定. $A$, 膜電位 $-100 \mathrm{mV}$ から $+50 \mathrm{mV}$ の各電位に固定し, $475 \mathrm{~nm}$ の青色光照射に応答するチャネル電流のトレース. 光照 射直後のピーク電流が steady state 電流に減衰する. 光を切ると 10 ミリ秒程度の時定数でチャネル電流は減衰. B, 膜電位と電流 值 (steady state) の関係（IN plot）. 内向き整流型の電位依存性 を示す.C，パルス光を 1 秒間の暗状態の間隔で照射した際の チャネル電流. $D$ ，パルス光を 1 分間の暗状態の間隔で 2 度照射 した際のチャネル電流
チャネル電流は 10 ミリ秒程度の時定数で減衰しゼロ となる。図 3B はA で得られた定常電流值と膜電位の 関係 (I/Vプロット) である。この図から，ChRの電流 值の膜電位依存性は直線から外れ，内向きにはイオン をよく通すが外向きには透過させにくい性質を持つ.

また断続的にパルス光を照射した場合，2回目の光 照射による初期ピーク電流は 1 回目のそれより低下寸 る (図 3C，矢印)。この初期ピーク電流が元の大きさ に回復するまでには 1 分から 2 分程度，暗状態を保つ 必要がある（図3D，矢印）。これはChRの光順応 (light adaptation）と呼ばれる，以上のような脱感作や 光順応は, クラミドモナスの生体内での光応答反応に とって重要と考えられており，例えば強い光による急 激な膜の脱分極を防ぐために備わっている性質なのか もしれない ${ }^{16)}$.

\section{2 チャネルゲーティング, キネティクス}

ChRのイオンの通り道とチャネルゲートは一体どこ にあるのか? 加藤らによるチャネルの閉じた結晶構造 によれば， 7 本の膜貫通へリックスのらち，1，2，7 番目のへリックスがキャビティーを形成しているため ここがイオン孔の一部であろら (図 4A 青) ${ }^{11}$. この キャビティーは all-trans 型レチナール近傍で塞がって いる。このことはこのチャネルのゲートがこの近傍に
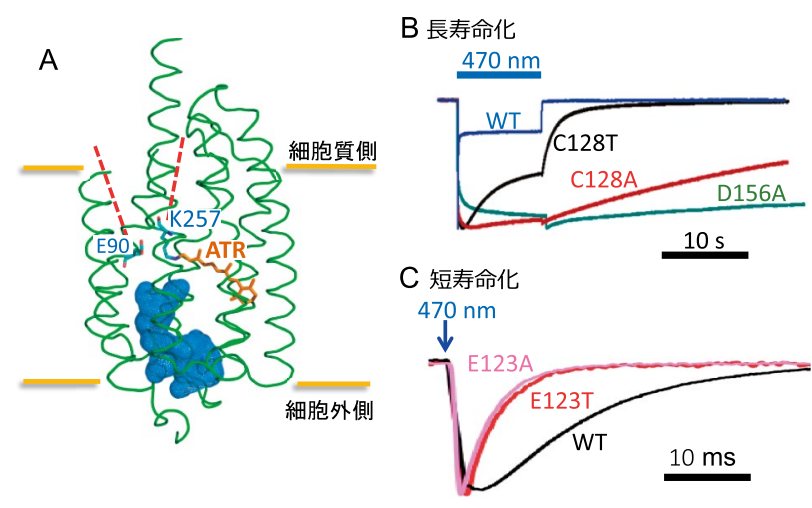

図 4

チャネル孔とチャネル電流キネティクス. A, チャネルロドプシ ンの結晶構造 (PDB accession number: 3UG9) ${ }^{11)}$. この構造はチャ ネルが閉じた状態とされる. 7 回膜貫通ヘリックス中に, 細胞外 側からタンパク質内部の all-trans 型レチナール (ATR) 近傍まで キャビティー（青色）が存在し，ここがイオン透過経路であると 予想される. 赤点線は推定される細胞質側のチャネル孔. 2 番目 膜貫通ヘリックスに存在する E90 やATR とシッフ塩基結合を形成 するK257などがチャネルゲートを形成している. B, ChR2 の チャネル長寿命変異体. 変異導入により $10^{2} \sim 10^{5}$ 倍も減衰の時 定数が大きくなる. C, ChR2 のチャネル短寿命変異体. フラッ シュ光 (10ナノ秒) 照射後のチャネル電流の減衰の時定数が変異 体は野生型の $1 / 4$ になる. B とC は時間スケールが 1000 倍異な ることに注意. 
存在することを示唆している，光吸収によるレチナー ルの異性化に伴う構造変化がこの近傍で起こりチャネ ルが開くといらシナリオが予想される。またレチナー ル近傍の特徵的なシステイン残基（ChR2の 128 番目 のシスティン残基（C128）に相当）とアスパラギン酸 残基（ChR2の 156 番目のアスパラギン酸残基（D56） 飞相当）の側鎖間の水素結合が $\mathrm{ChR}$ の光サイクル反応 の速度を決めることがわかっている ${ }^{12}$ 。 この部位へア ミノ酸変異を導入すると，レチナールの異性化状態が 安定化されるためチャネル開寿命が長くなる(図 4B). 前述した通り, ChR2 の野生型では光遮断後のチャネ 儿電流の減衰の時定数が 10 ミリ秒程度だが，変異導 入により $10^{2}$ から $10^{5}$ 倍も大きくなる ${ }^{13), 14)}$. 従って光 を遮断後もチャネル電流が数秒から数分にわたり流れ 続ける (図 4B)。これらの変異体はStep Function Op$\sin (\mathrm{SFO})$ と呼ばれ神経細胞の活性化のための光遺伝 学ッールとして広く利用されている ${ }^{15}$.

一方，レチナール近傍のグルタミン酸残基（ChR2 の 123 番目のグルタミン残基（E123）に相当）への 変異導入はチャネル開状態を不安定化するため開寿命 が短くなる．図 4C に示すよらにフラッシュ光照射後 のチャネルの減衰が野生型（10ミリ秒）の拈よそ2.5 倍の 4 ミリ秒に加速する ${ }^{16)}$.

\section{$3.3 \mathrm{ChR}$ のイオン選択性}

電位依存性カリウムチャネルやナトリウムチャネ ル，カルシウムチャネルといったイオン選択性の高い チャネル分子に扎いては，そのチャネル孔内部に選択 フィルターと呼ばれる，特定のイオンだけを通すフィ ルタ一構造が存在する ${ }^{17)}$. ChR に䄧いては, その結晶 構造を見ても特定のイオンだけを選択する構造は見当 たらない (図 4A $)^{11)}$ 。実際 $\mathrm{ChR}$ はプロトン, $\mathrm{Li}^{+}, \mathrm{Na}^{+}$, $\mathrm{K}^{+}, \mathrm{Rb}^{+}, \mathrm{Cs}^{+}, \mathrm{Ca}^{2+}, \mathrm{Mg}^{2+}$ を透過するが5)，プロトンの 透過性は $\mathrm{Na}^{+}$そ水と比較して $10^{5} \sim 10^{6}$ 倍と極めて高 いためプロトンチャネルと言っても良い，実際 ChR1 が発見された際はプロトンだけを通すと報告された帛 (後に ChR2 と同様に他のイオンも通すことが確認さ れた $\left.{ }^{18)}\right)$ 。乙かしながら生理的環境下に执いてプロト ン濃度は $0.1 \mu \mathrm{M}$ 程度と非常に低く, また $\mathrm{Na}^{+}$は 100 $\mathrm{mM}$ 程度と高いので見かけ上プロトンと $\mathrm{Na}^{+}$の透過量 は同程度になる。また $\mathrm{Ca}^{2+}$ の透過性は $\mathrm{Na}^{+}$の $10 \%$ 程 度である. チャネル孔を形成するアミノ酸残基置換に よりイオン透過性は変化する ${ }^{19)}$. 例光ば, ChR2 の 132 番目のロイシン（L）をシステイン（C）飞置換した ChR2 L132C 変異体ではカルシウムイオン透過性が上 昇する ${ }^{20)}$ 。をた図 4A で示した2 番目のーリックス中
の 90 番目のグルタミン酸残基（E90）は特にイオン 透過性に重要な残基である。この負電荷を持つ残基を 正電荷を持つリジン（K）やアルギニン（R）飞置換 するとカチオンではなくアニオンを透過するチャネル に機能転換できる (Chloride-conducting ChR, 略して $\mathrm{ChloC}^{21)}$ ）。たカチオンチャネルからアニオンチャネ ルへの転換は他の変異でも可能であるがそのためには チャネル孔付近の 9 か所の变異導入が必要である ${ }^{22}$.

\section{4 単一チャネル透過性 single channel conductance}

図 3A, B の光照射によるチャネル電流測定では細胞 膜上に発現している多くの ChR2 分子のチャネル活性 の総和を測定していた．ところでChRの一分子あたり のイオン透過性（single channel conductance）はぞれく らいだろらか? パッチクランプ法を用いてイオンチャ ネル一分子の活性計測が可能だが，ChRに扔いては その透過性は非常に低いためシグナルの検出が非常に 困難である。その代りに多分子チャネル測定（通常の パッチクランプ測定）で得られたデータのノイズ解析 から単一チャネルイオン透過性が見積もられた ${ }^{23)}$. そ れによればChR2 に扔いては拉よそ40 fSであった。一 般的なナトリウムチャネルやカリウムチャネルはこの 值が打打よそ10-50 pS であるから ChR のイオン透過 性は 250 分の 1 以下と非常に小さい. 一方 2015 年に 報告された光開閉型アニオンチャネルである ACR の 単一チャネル透過性は打よそ $600 \mathrm{fS}$ と見積もられて拉 り ChR2よりも 15 倍も高い透過性を示す9).

\section{4.}

\section{1 フォトサイクルと電気生理学測定}

BRなぞのプロトンポンプに扮いては，その光サイ クル反応の詳細な解析によりプロトン輸送機構が調へ られてきた，それによると，光吸収によるレチナール の all-trans 型から 13-cis 型への異性化に伴い, プロト ンを結合したレチナールシッフ塩基が脱プロトン化さ れ，このプロトンがまず細胞外へ放出される。そ後 細胞質側からロドプシン分子内にプロトンが取り込ま れレチナールシッフ塩基がプロトン化することで，正 味 1 プロトンが輸送される ${ }^{1)}$. つまりポンプはフォト サイクルが 1 回転するごとにイオンを 1 つしか運ばな い.この点はフォトサイクルが 1 回転しただけで多く のイオンを透過するチャネルとは異なる.

前述したよらに BRや HR ぞ古細菌由来のプロト ンポンプや塩化物イオンポンプをはじめとするポンプ 型ロドプシンの電気生理学測定は，人工平面膜を用い 


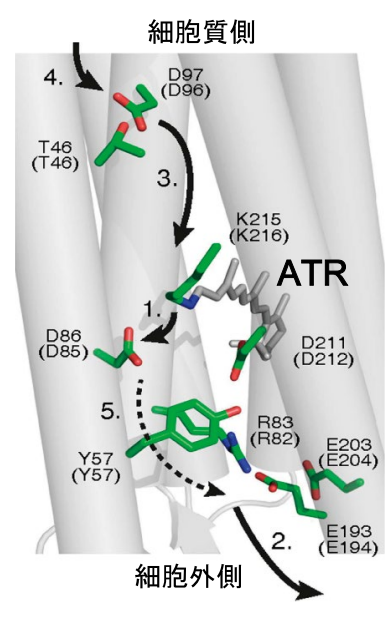

図 5

プロトンポンプロドプシン分子内のプロトン透過過程. 1 から 5 で示したステップでプロトンが輸送される. CsRにおけるプロト ン輸送に重要なアミノ酸を示す. カッコ内の数字はBRにおける アミノ酸. 光吸収により all-trans 型レチナール（ATR）が異性化 することでプロトン化シッフ塩基から D86 にプロトンが移動する と (1), Y57 と R83 の構造が細胞外側にフリップすることで E193 から細胞外側にプロトンが放出される（2）．その後 D97 か らのプロトンによりシッフ塩基がプロトン化される（3）. 細胞質 のプロトンより D97 がプロトン化され (4), 最後はD86 から E193 にプロトンが移り（5）始状態に戻る（文献 27 より).

た実験が 1990 年代に行われており，その後アフリカ ツメガエル卵母細胞を用いた二電極電位固定法や HEK293 細胞等を用いたパッチクランプ測定が行われ てきた ${ }^{24), 25)}$. 図 2 で示したよらにポンプ電流はチャ ネルとは異なり基本的に一方向の能動輸送なので膜電 位を変えても流れる電流の向きは不変である。図6A にクロレラ由来（Coccomyxa subellipsoidea C-169）のプロ トンポンプロドプシン（CsR）の電位固定法を用いた 電流測定を示す。CsR は BR と 37\% の相同性を示すプ ロトンポンプである. $550 \mathrm{~nm}$ の光照射に伴い細胞質 から細胞外へのプロトンの輸送に対応する上向きの電 流が得られる。測定膜電位の範囲 $(-120 \sim+60 \mathrm{mV})$ に敃いて見かけの電流值は膜電位の上昇に伴い大きく なる（図6B）。先に書いたがイオンポンプ型ロドプシ ンでは 1 反応サイクルで輸送されるイオンは 1 つと決 まっている ${ }^{1)}$.つまりロドプシンの 1 光子の吸収とと もに輸送するのは 1 イオンのみである. 膜電位が上昇 することによる見かけの電流の増大は何を意味するの だろらか?これは膜電位の上昇とともにフォトサイク ルが加速するといらことである。つまりフォトサイク ル反応中に膜電位依存的なステップが含まれている. GeibelらはBRに㧧ててプトンの取り込みステップ （図 5 の矢印 3，4のステップ）が電位依存的である ことを確かめた ${ }^{25)}$.

ところで, 膜電位 $(E)$ と, 膜内外のプロトン濃度
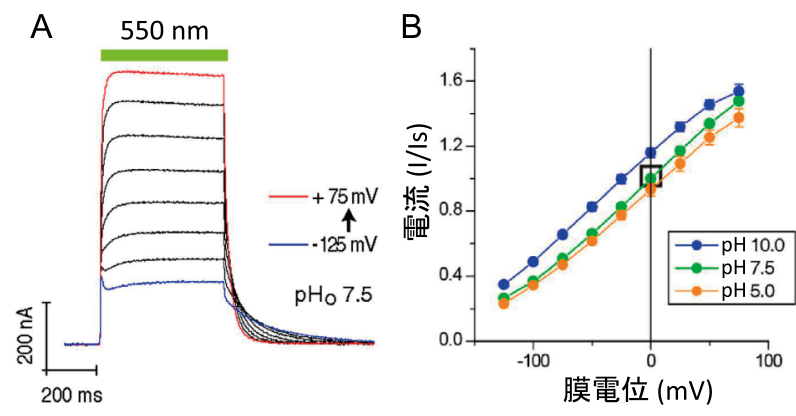

図 6

CsR のプロトンポンプ機能. CsR をアフリカツメガエル卵母細胞 に発現させその光電流を測定した. A, 各膜電位におけるポンプ 電流. $B$, 膜電位と電流値の関係 (INプロット). 細胞外溶液の $\mathrm{pH}$ をそれぞれ 5.0, 7.5, 10.0 にて測定.

差 $(\Delta \mathrm{pH})$ は熱力学的には等価であり以下のネルンス トの式から $E$ と $\Delta \mathrm{pH}$ には以下の関係が成立する.

$$
E=\frac{R T}{F} \ln \frac{\left[\mathrm{H}_{\mathrm{o}}\right]}{\left[\mathrm{H}_{\mathrm{i}}\right]}
$$

ここで，Rは気体定数， $T$ は絶対温度，Fはファラ ディ定数. $\left[\mathrm{H}_{\mathrm{i}}\right]$ と $\left[\mathrm{H}_{\mathrm{o}}\right]$ は膜内外のプロトン濃度である. $\mathrm{RT} / \mathrm{F}$ の項は $20^{\circ} \mathrm{C}$ においておよそ58なので膜内外の $\mathrm{pH}$ 差 $(\Delta \mathrm{pH})=1.0$ は膜電位 $(E)$ の $58 \mathrm{mV}$ に相当する. それでは，プロトンポンプロドプシン分子にとって $\Delta \mathrm{pH}$ と $E$ は見かけ上ポンプ活性に与える効果は同じ だろらか? 答えはNoである。必ずしもそれは等価で はないといらことが複数の電気生理学実験からわかっ ている ${ }^{24)-26)}$. 図 6B の I/V プロットから電流值は $E$ の 上昇に伴い大きくなることは先に述べた. しかし $\Delta \mathrm{pH}$ を変化させても（例えば図 6B の pH 7.5 とH 5.0 だ と $\Delta \mathrm{pH}=2.5$ となる） ポンプ電流の大きさにほとんど 変化がない.つまりフォトサイクルの速さに変化がな いことを意味する。 このようにポンプ型ロドプシンに とって $E$ と $\Delta \mathrm{pH}$ は反応速度に対しては等価ではない。

\section{2 ポンプのカ, エネルギー障壁}

イオンポンプは膜電位やイオン濃度勾配に逆らって でもイオンを輸送すると最初に書いたが，ポンプ型ロ ドプシンに拈いては実際どれくらいのエネルギー障壁 (電気化学ポテンシャル差) に耐えて能動輸送が可能 なのだろらか? 膜電位差 $(E)$ についていえば答えは 割と簡単で，図6Bに示した I/Vプロットを外挿して 電流值 $=0$ になる電位を求めればそれがそのポンプの 起電力といらことになる. BR や CsR な゙のプロトン ポンプではその值が扎よそー200〜 - $250 \mathrm{mV}$ であるこ とがわかっている ${ }^{25)-28)}$.

しかし前項で述べた通り， $E$ と $\Delta \mathrm{pH}$ はプロトンポ 


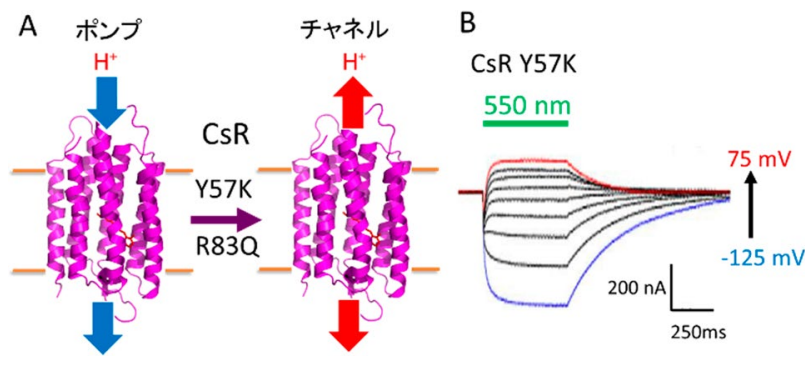

図 7

プロトンポンプからプロトンチャネルへ機能改変. $A$, プロトン ポンプ（CSR）のプロトンゲート残基に変異導入（Y57Kまたは R83Q）するとプロトンチャネルとして機能する. B, CSRY57K 変 異体の光照射による電流応答. 膜電位により電流の向きが変わる.

ンプロドプシンにおいては必ずしも等価に作用しな い.となると $\Delta \mathrm{pH}$ に対してはどの程度の起電力を持 つのだろらか? ポンプ活性の $\Delta \mathrm{pH}$ 依存性を測定して みると，その起電力は $-350 \mathrm{mV}$ 以上にもなることが わかっている ${ }^{25), 26)}$ 。これをプロトン濃度差に換算す ると， $\Delta \mathrm{pH}=6.0$ に相当する．つまり百万倍（！）の 濃度差に逆らってでもプロトンを輸送できることを意 味する。

\section{5.}

\section{ポンプとチャネル，機能伝換}

チャネル分子内のイオン透過の仕組みを単純化して みるとチャネル孔に 1 か所ゲートを設けて，それを開 閉すれば電気化学ポテンシャルに応じてイオンが透過 しチャネルとして機能する。一方イオンポンプの場合 それ流純ではない。イオンの通り道に最低 2 か所 のゲートを設けてそれを交互に開閉し，かつ適切なタ イミングでイオンを押し出す機構があれば一方向の輸 送が可能である. BR の結晶構造から 2 か所のゲート のらち 1 つは 57 番目のチロシン残基（Y57）と 82 番 目のアルギニン残基（R82）により形成されることが わかっている（図 5)。だとするとこのゲートを開け たままにすれば，ゲートは残り1つだけになり，ポン プがチャネルになってしまうのだろらか？実際 CsR のこれらゲート残基（Y57またはR83）に変異を加え ると，1アミノ酸置換でプロトンポンプ（図 6A）か らプロトンチャネルヘと機能が変わることが示された (図 7A, B ${ }^{27)}$. よって Y57 と R82 により形成される ゲートは，プロトン輸送に拈いてイオンの逆流を防ぐ 役割を担っているのだろら。

\section{6.}

\section{おわりに}

ChRやプロトンポンプロドプシンの機能は電気生
理学に加え, 分光学的手法を用いた研究から光受容体 としての特性もよく調べられてきた。一方，汪とんど 触れなかったが，近年新たに発見されたアニオンチャ ネルロドプシン (ACR)，ナトリウムポンプ $(\mathrm{NaR})$ そ して内向きプロトンポンプ (PoXeR) 等について電気 生理学測定によるイオン透過性の実験は始まったばか りである. 今後の研究によりこれら分子の機能メカニ ズムとそれぞれの違いが明らかになると期待される。

謝 辞

イオン輸送型ロドプシンの電気生理学実験を遂行す るにあたり名古屋工業大学，神取秀樹教授およびドイ ツフンボルト大学 Peter Hegemann 教授には様々なご支 援ご協力をいただきました。この場を借りて感謝申し 上げます。

文 献

1) Ernst, O. P. et al. (2014) Chem. Rev. 114, 126-163. DOI: 10.1021/ cr4003769.

2) Inoue, K. et al. (2013) Nat. Commun. 4, 1678. DOI: 10.1038/ ncomms 2689 .

3) Inoue, K. et al. (2016) Nat. Commun. 7, 13451. DOI: 10.1038/ ncomms 13415.

4) Nagel, G. et al. (2002) Science 296, 2395-2398. DOI: 10.1126/ science. 1072068

5) Nagel, G. et al. (2003) Proc. Natl. Acad. Sci. USA 100, 1394013945. DOI: 10.1073/pnas.1936192100.

6) Ernst, O. P. et al. (2008) J. Biol. Chem. 283, 1637-1643. DOI: 10.1074/jbc.M708039200.

7) Boyden, E. S. et al. (2005) Nat. Neurosci. 8, 1263-1268. DOI: $10.1038 / \mathrm{nn} 1525$.

8) Ishizuka, T. et al. (2006) Neurosci. Res. 54, 85-94. DOI: 10.1016/ j.neures.2005.10.009.

9) Govorunova, E. G. et al. (2015) Science 349, 647-650. DOI: $10.1126 /$ science.aaa 7484

10）岡田泰伸（2001）新パッチクランプ実験技術穂，吉岡書店, 京都.

11) Kato, H. E. et al. (2012) Nature 482, 369-374. DOI: 10.1038/ nature10870.

12) Nack, M. et al. (2010) Photochem. Photobiol. Sci. 9, 194-198. DOI: $10.1039 / \mathrm{b} 9 \mathrm{pp} 00157 \mathrm{c}$.

13) Bamann, C. et al. (2010) Biochemistry 49, 267-278. DOI: 10.1021/bi901634p.

14) Hososhima, S. et al. (2015) PLoS ONE 10, e0119558. DOI: 10.1371/journal.pone.0119558.

15） Berndt, A. et al. (2009) Nat. Neurosci. 12, 229-234. DOI: 10.1038/ nn.2247.

16) Gunaydin, L. A. et al. (2010) Nat. Neurosci. 13, 387-392. DOI: 10.1038/nn.2495.

17) Doyle, D. A. et al. (1998) Science 280, 69-77. DOI: $10.1126 /$ science.280.5360.69.

18) Tsunoda, S. P., Hegemann, P. (2009) Photochem. Photobiol. 85, 564-569. DOI: $10.1111 / j .1751-1097.2008 .00519 . x$. 
19) Sugiyama, Y. et al. (2009) Photochem. Photobiol. Sci. 8, 328-336. DOI: $10.1039 / \mathrm{b} 815762 \mathrm{f}$

20) Kleinlogel, S. et al. (2011) Nat. Neurosci. 14, 513-518. DOI: 10.1038/nn.2776

21）Wietek, J. et al. (2014) Science 344, 409-412. DOI: 10.1126/ science. 1249375 .

22) Berndt, A. et al. (2014) Science 344, 420-424. DOI: $10.1126 /$ science. 1252367

23) Feldbauer, K. et al. (2009) Proc. Natl. Acad. Sci. USA 106, 12317 12322. DOI: $10.1073 /$ pnas.0905852106.

24) Muneyuki, E. et al. (1996) J. Phys. Chem. 100, 19687-19691. DOI: $10.1021 /$ jp961514g.

25) Geibel, S. et al. (2001) Biophys. J. 81, 2059-2068. DOI: 10.1016/ S0006-3495 (01) 75855-9.

26) Tsunoda, S. P. et al. (2006) Biophys. J. 91, 1471-1479. DOI 10.1529/biophysj.106.086421.

27）Vogt, A. et al. (2015) Sci. Rep. 5, 1-13. DOI: 10.1038/srep16450.

28）Vogt, A. et al. (2013) Biophys. J. 105, 2055-2063. DOI: 10.1016/ j.bpj.2013.08.031.

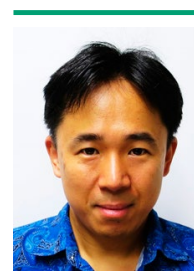

角田 聡

角田 聡 (つのだ さとし)

科学技術振興機構さきがけ専任研究員, 名古屋工 業大学客員准教授

2002 年東京工業大学大学院総合理工学研究科修

了. ベルリンフンボルト大学博士研究員などを経 て現職.

研究内容: 微生物型ロドプシンの機能解析と光遺 伝学への応用

連絡先: $7466-8555$ 愛知県名古屋市昭和区御器 所町

E-mail: tsunoda.satoshi@nitech.ac.jp URL: http://www.jst.go.jp/kisoken/presto//project/ 1112076/16814641.htm 